\title{
PENGARUH KEPUASAN PELANGGAN, CITRA MEREK, HARGA DAN KUALITAS PRODUK TERHADAP LOYALITAS PELANGGAN PADA HANDPHONE XIAOMI DI YOGYAKARTA
}

\author{
Indri Hastuti Listyawati ${ }^{1}$ \\ ${ }^{1}$ Akademi Manajemen Administrasi YPK Yogyakarta \\ myindri.kla10@gmail.com
}

\begin{abstract}
The purpose of this study is to determine the effect of customer satisfaction, brand image, price, and product quality on consumer loyalty decisions on Xiaomi mobile phone in Yogyakarta.

The population in this research is the user of Xiaomi mobile phone in Yogyakarta. While the sample in this study is the user of Xiaomi note 4. This study is using the primary data, the data obtained directly from the source. Primary data in this study is the answer from consumers who become respondents. In this study researcher used survey methods. Survey method is a research method implemented by taking samples from a population and using questionnaires. This study uses convenience sampling technique that is because of the ease of sampling.

The results showed that the customer satisfaction, price, brand image and product quality significantly influence the customer loyalty on Xiaomi note 4 in Yogyakarta. These results indicate that customer satisfaction, price, brand image and product quality can create customer loyalty.
\end{abstract}

Keywords: Customer Satisfaction, Price, Brand Image, Product Quality, Customer Loyalty.

(C) 2018 JBTI. All rights reserved

Article history : received 1 Jan 2018; revised 11 Jan 2018 ; accepted 18 Jan 2018

\section{PENDAHULUAN}

Ketika konsumen memutuskan untuk membeli suatu produk sebenarnya konsumen memiliki alasan-alasan tertentu dalam memilih sebuah produk, misalnya merasa puas dengan kualitas dan pelayanan yang ditawarkan produk tersebut. Ada pula konsumen yang membeli barang berdasarkan kebutuhan akan suatu barang dan tidak sedikit konsumen yang membeli suatu produk secara spontanitas.

Mencermati perkembangan pasar, bahwa permintaan terhadap handphone terus bertambah, hal ini menunjukkan bahwa pengguna handphone semakin banyak. Di antara berbagai merek Handphone yang ada, Xiaomi adalah salah satu smartphone yang banyak diminati.

Xiaomi sebagai salah satu smartphone pendatang baru, perlu memiliki kelebihan agar dapat bersaing dengan smartphone lainnya. Agar dapat memenangkan persaingan, maka perusahaan dituntut untuk menawarkan produk yang mempunyai nilai lebih, sehingga dapat menarik minat konsumen dan untuk jangka panjang dapat menjadi pelanggan yang setia. Diantaranya yang pasti adalah memberikan kepuasan melalui produk yang berkualitas, harga yang terjangkau, dan yang tidak kalah pentingnya adalah merek yang mampu memberikan garansi bahwa produk yang dijual itu berkualitas.

Kualitas produk dapat disampaikan melalui ciri-ciri produk berwujud, salah satunya adalah manfaat dari produk itu. Kualitas produk adalah keadaan fisik, fungsi dan sifat suatu produk bersangkutan yang dapat memenuhi selera dan kebutuhan konsumen dengan memuaskan sesuai 
nilai uang yang telah dikeluarkan (Prawirosentono, 2004). Didalam pembelian konsumen biasanya memperhatikan bagaimana kualitas produk yang ditawarkan berkenaan dengan manfaat yang akan diperolehnya apakah sesuai dengan yang diharapkan atau tidak. Menurut Tjiptono (2002) kualitas produk merupakan keunggulan untuk memenuhi harapan pelanggan.

Selain faktor kualitas produk, harga dan citra merek suatu produk menjadi alasan konsumen membeli sebuah produk. Harga sangat penting dalam mempengaruhi kepuasan pelanggan. Jika harga tinggi maka permintaan produk semakin rendah dan jika harga bersaing maka permintaan produk akan semakin meningkat. Jika harga yang ditetapkan perusahaan tepat dan sesuai dengan daya beli konsumen maka pemilihan suatu produk akan dijatuhkan pada produk tersebut (Dharmmesta dan Irawan, 2002).

Selain citra dari sebuah produk dapat mempengaruhi loyalitas pelanggan, Kandampully \& Suhartono (2000) menyatakan jika konsumen merasakan citra yang bagus maka niat berperilaku mereka adalah positif seperti: keinginan untuk membeli ulang pada merek yang sama, meningkatkan pembelian dan berkeinginan untuk merekomendasikan merek tersebut kepada orang lain (suatu ukuran loyalitas konsumen).

Berdasarkan uraian di atas, maka peneliti tertarik untuk melakukan penelitian tentang Pengaruh Kepuasan Pelanggan, Citra Merek, Harga dan Kualitas Produk terhadap Loyalitas Pelanggan Pada Handphone Xiaomi di Yogyakarta.

\section{KAJIAN TEORI}

\section{Kepuasan Pelanggan}

Tjiptono (2007) menjelaskan kepuasan dapat diartikan sebagai upaya pemenuhan sesuatu atau membuat sesuatu memadai. Kepuasan pelanggan juga merupakan fungsi dari harapan pembeli atas produk atau jasa dengan kinerja yang dirasakan (Cronin et al., 2000). Selnes (1993) menyatakan kepuasan dinilai secara langsung sebagai perasaan keseluruhan. Maka seseorang dapat puas dengan produk atau jasa utama dan pada saat yang sama mengevaluasi hasil seperti rata-rata dibandingkan dengan yang seharusnya. Selain itu, kepuasan dapat dinilai secara langsung sebagai perasaan keseluruhan. Perasaan yang merupakan akumulasi pengalaman pembelian konsumen dan pengalaman konsumsi (Andreassen, 1994).

\section{Citra merek}

Citra Merek adalah persepsi tentang merek yang merupakan refleksi memori konsumen akan asosiasinya pada merek tersebut (Ferrinadewi, 2008). Sedangkan citra menurut Kotler dan Keller (2012) adalah sejumlah keyakinan, ide, dan kesan yang dipegang oleh seseorang tentang sebuah objek.

Komponen dari Citra Merek menurut Xian, dkk (2011) terdiri dari citra perusahaan, citra pemakai dan citra produk. Citra perusahaan merupakan gambaran perusahaan di mata konsumen berdasarkan pengetahuan, tanggapan serta pengalaman konsumen terhadap perusahaan yang bersangkutan. Citra pemakai merupakan sekumpulan karakteristik dari konsumen yang dihubungkan dengan ciri khas dari konsumen suatu merek. Sedangkan citra produk merupakan gambaran produk di mata konsumen berdasarkan pengetahuan, tanggapan serta pengalaman konsumen terhadap produk yang bersangkutan. 


\section{Harga}

Harga dapat menunjukkan kualitas merek dari suatu produk, dimana konsumen mempunyai anggapan bahwa harga yang mahal biasanya mempunyai kualitas yang baik. Pada umumnya harga mempunyai pengaruh yang positif dengan kualitas, semakin tinggi harga maka semakin tinggi kualitas. Selain itu, harga juga merupakan strategi puncak untuk mendapatkan keuntungan bagi perusahaan. Keputusan tentang penetapan harga perlu ditegaskan dengan keputusan tentang barang.

Harga adalah nilai suatu barang atau jasa yang diukur dengan sejumlah uang berdasarkan nilai tersebut seseorang atau perusahaan bersedia melepas barang atau jasa yang dimiliki kepada pihak lain (Kotler, 2002). Pelanggan yang loyal juga akan memperhatikan harga yang ditetapkan atas produk yang digunakannya.

\section{Kualitas produk}

Kualitas mempunyai dampak terhadap kepuasan pelanggan konsumen. Apabila kualitas produk yang dihasilkan baik maka konsumen cenderung loyal dan tentunya melakukan pembelian ulang. Tetapi, seandainya kualitas produk tidak sesuai dengan harapan maka konsumen akan beralih pada produk sejenis lainnya. Kualitas produk dapat juga dijelaskan sebagai totalitas fitur dan karakteristik produk atau jasa yang bergantung pada kemampuannya untuk memuaskan kebutuhan yang dinyatakan atau tersirat (Kotler dan Amstrong, 2008).

\section{Loyalitas Pelanggan}

Selnes (1993) menjelaskan loyalitas pelanggan menunjukkan perilaku yang dimaksudkan berkaitan dengan produk atau jasa. Hal ini termasuk kemungkinan pembelian mendatang atau pembaharuan kontrak jasa atau sebaliknya, seberapa mungkin konsumen akan beralih ke penyedia jasa atau merek lainnya. Loyalitas pelanggan terhadap suatu merek perusahaan, sangat tergantung pada kemampuan perusahaan mengelola faktor-faktor yang mempengaruhi loyalitas merek. Studi yang dilakukan oleh Sugandini (2002) menyimpulkan terdapat empat faktor yang membentuk loyalitas pelanggan yaitu citra merek, persepsi kualitas, nilai dan kepuasan konsumen.

Konsumen juga dapat menjadi loyal karena puas dengan pemasok atau merek produk, sehingga ingin terus melanjutkan hubungan. Karena kebanyakan hambatan terbatas daya tahannya, perusahaan cenderung mendekati kepuasan sebagai strategi yang potensial dalam jangka panjang. Menjaga kepuasan konsumen adalah sebuah keharusan bagi perusahaan. Karena memuaskan konsumen adalah tujuan perusahaan. Sehingga dalam jangka panjang konsumen yang puas itu dapat menjadi loyal karena telah mendapatkan kepuasan (Ranto, 2014).

\section{Tinjauan Penelitian Terdahulu}

Berikut adalah beberapa hasil penelitian terdahulu yang terkait dengan penelitian yang dilakukan peneliti saat ini:

Berdasarkan penelitian yang dilakukan oleh Sugandini (2002) menyimpulkan terdapat empat faktor yang membentuk loyalitas pelanggan yaitu citra merek, persepsi kualitas, nilai dan kepuasan konsumen. Studi lain juga dilakukan oleh Ranto (2017) menjelaskan bahwa Kepuasan pelanggan berpengaruh positif terhadap loyalitas pelanggan. Tomida dan Satrio (2016) menambahkan dalam studinya bahwa harga dan citra merek memiliki dampak yang signifikan terhadap pembentukan loyalitas pelanggan pada produk sepatu Yongki Komaladi di Surabaya. Selain itu, Suwarni dan Mayasari (2011) menambahkan bahwa melalui kepuasan pelanggan, loyalitas pelanggan dapat dipengaruhi oleh kualitas produk dan harga. 


\section{Kerangka Konseptual}

Model konseptual penelitian yang dapat disusun dalam penelitian ini adalah:

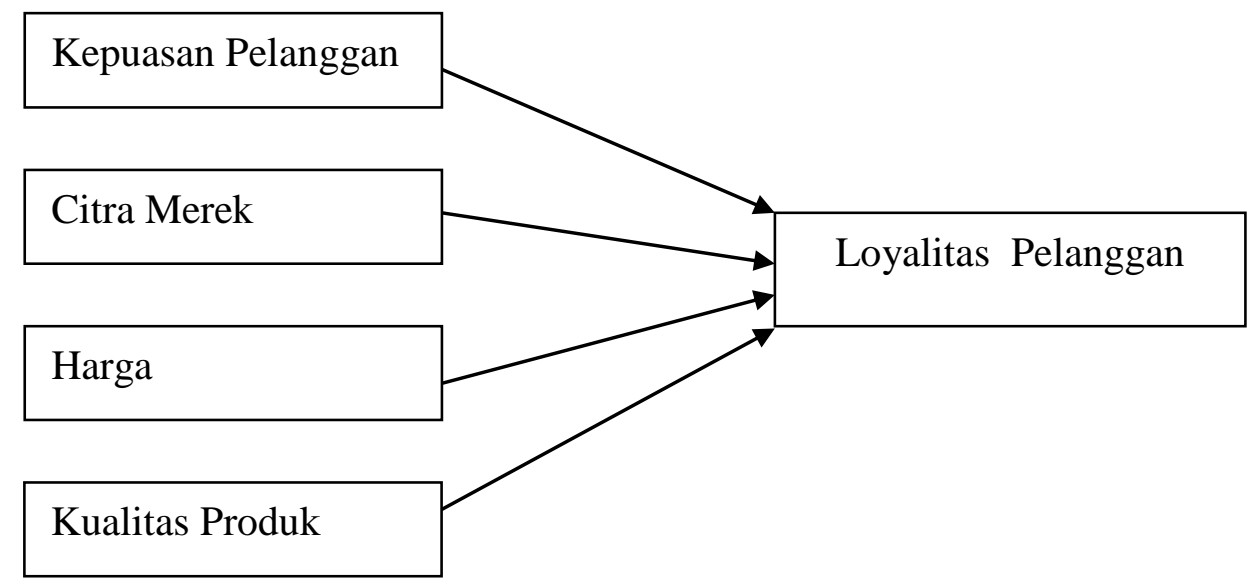

Gambar 1. Model Penelitian

\section{Hipotesis Penelitian}

Berdasarkan model penelitian tersebut maka hipotesis yang dapat disusun adalah:

H1 : Diduga Kepuasan Pelanggan berpengaruh positif terhadap Loyalitas Pelanggan pada handphone Xiaomi di Yogyakarta.

H2 : Diduga citra merek berpengaruh positif terhadap Loyalitas Pelanggan pada handphone Xiaomi di Yogyakarta.

H3 : Diduga harga berpengaruh positif terhadap Loyalitas Pelanggan pada handphone Xiaomi di Yogyakarta.

H4 : Diduga kualitas produk berpengaruh positif terhadap Loyalitas Pelanggan pada handphone Xiaomi di Yogyakarta.

\section{METODE PENELITIAN}

\section{Populasi dan Sampel}

Populasi dalam penelitian ini adalah pengguna handphone Xiaomi di Yogyakarta. Sedangkan sampel penelitiannya adalah para pengguna handphone Xiaomi seri note 4. Penelitian ini menggunakan teknik convenience sampling yaitu pengambilan sampel karena faktor kemudahan.

\section{Jenis dan Sumber Data}

Data yang digunakan dalam penelitian ini adalah data primer, yaitu data yang diperoleh secara langsung dari sumbernya (Arikunto, 2012). Data primer dalam penelitian ini adalah jawaban dari konsumen yang menjadi responden. 


\section{Teknik Pengumpulan Data}

Peneliti menggunakan metode survei dalam penelitian ini. Metode survei merupakan metode penelitian yang dilaksanakan dengan mengambil sampel dari suatu populasi dan menggunakan kuesioner (Sekaran, 2000). Kuesioner disampaikan secara langsung oleh peneliti kepada responden dan dikembalikan lagi kepada peneliti.

\section{Definisi Operasional Variabel Penelitian}

1. Kepuasan Pelanggan (X1) adalah merupakan perasaan senang atau kecewa seseorang yang dialami setelah membandingkan antara persepsi kinerja atau hasil suatu produk dengan harapanharapannya (Kotler, 2003).

2. Citra merek (X2) adalah persepsi dan keyakinan yang dipegang oleh konsumen, seperti yang dicerminkan asosiasi yang tertanam dalam ingatan konsumen (Kotler dan Keller, 2009).

3. Harga (X1) adalah jumlah yang dibayarkan oleh pembeli untuk dapat menikmati manfaat yang dapat diberikan oleh suatu barang (Tjiptono, 2002).

4. Kualitas produk (X3) adalah totalitas fitur dan karakteristik produk atau jasa yang bergantung pada kemampuannya untuk memuaskan kebutuhan yang dinyatakan atau tersirat (Kotler dan Amstrong, 2012).

5. Loyalitas pelanggan (Y) menunjukkan perilaku yang dimaksudkan berkaitan dengan produk atau jasa. Hal ini termasuk kemungkinan pembelian mendatang atau pembaharuan kontrak jasa atau sebaliknya, seberapa mungkin konsumen akan beralih ke penyedia jasa atau merek lainnya (Selnes, 1993).

\section{Uji Kualitas Instrumen}

1. Uji Validitas

Uji validitas digunakan untuk menguji kemampuan alat ukur dalam mengukur konstruk (Tjahjono, 2015). Pengujian penelitian ini dilakukan dengan menggunakan korelasi Product Moment. Instrumen penelitian dikatakan valid apabila nilai signifikansi lebih kecil dari 5\%. Uji validitas dilakukan dengan bantuan program SPSS for windows 20. Dari uji validitas yang dilakukan, hasilnya menunjukkan bahwa keseluruhan butir pernyataan dinyatakan valid karena nilai signifikansi lebih kecil dari 0,05 .

2. Uji Reliabilitas

Uji Pada penelitian ini untuk mengukur reliabilitas dilakukan dengan uji statistik Cronbach Alpha (a). Suatu variabel dikatakan reliabel jika memberikan nilai Cronbach Alpha > 0,60 (Sekaran, 2000). Berdasarkan uji reliabelitas yang dilakukan, hasilnya menunjukkan bahwa keseluruhan butir pernyataan dinyatakan reliable karena nilai cronbach's alpha semuanya di atas 0,60 .

\section{HASIL PENELITIAN}

\section{Karakteristik Responden}

Berdasarkan hasil penelitian yang diperoleh maka karakteristik responden dapat dijelaskan yaitu berdasarkan jenis kelamin: laki-laki berjumlah sebanyak 26 orang $(26,8 \%)$, sedangkan wanita berjumlah sebanyak 71 orang $(73,2 \%)$.

Sedangkan untuk usia: responden dibawah 25 tahun sebanyak 17 orang (17,5\%), 25 - 35 tahun sebanyak 44 orang $(45,4 \%)$, di atas 35 - 45 tahun sebanyak 26 orang $(26,8 \%)$, di atas 45 tahun sebanyak 10 orang $(10,3 \%)$. 
Berdasarkan Pendapatan: Kurang dari Rp. 1.000.000,- sebanyak 29 orang (29,9\%), Rp. 1.000.000 - Rp. 2.500.000,- sebanyak 33 orang (34,0\%), di atas Rp. 2. 500.000 - Rp. 3.500.000,sebanyak 24 orang $(24,7 \%)$, dan di atas Rp. 3.500 .000 sebanyak 11 orang (11,3\%).

\section{Uji Hipotesis}

Analisis regresi berganda digunakan untuk mengetahui pengaruh variabel kepuasan pelanggan, citra merek, harga dan kualitas produk terhadap loyalitas pelanggan. Berikut adalah hasil analisis regresi berganda:

Tabel 1. Hasil Analisis Regresi

\begin{tabular}{|l|c|c|c|}
\hline \multicolumn{1}{|c|}{ Variabel } & $\begin{array}{c}\text { Standardized } \\
\text { Coefficients (Beta) }\end{array}$ & $\mathrm{t}$ hitung & Signifikansi \\
\hline Kepuasan Pelanggan (X1) & 0.194 & 2.146 & 0.035 \\
\hline Citra Merek (X2) & 0.204 & 2.378 & 0.019 \\
\hline Harga (X3) & 0.284 & 3.351 & 0.001 \\
\hline Kualitas produk (X4) & 0.288 & 3.177 & 0.002 \\
\hline F hitung & & & 0.000 \\
\hline R & \multicolumn{3}{|c}{0.804} \\
\hline Adjusted R Square & \multicolumn{3}{|c}{0.631} \\
\hline
\end{tabular}

Berdasarkan hipotesis 1 yang menyatakan bahwa ada pengaruh positif variabel kepuasan pelanggan terhadap loyalitas pelanggan dapat ditunjukkan dengan melihat Tabel 1 bahwa nilai signifikansi variabel kepuasan pelanggan (X1) berada di bawah 0.05 , yaitu 0,035 yang berarti bahwa hasil pengujian signifikan pada taraf nyata 5\% sehingga dapat dijelaskan variabel kepuasan pelanggan (X1) mempunyai pengaruh yang signifikan terhadap loyalitas pelanggan. Sehingga dapat disimpulkan $\mathrm{H} 1$ dapat diterima.

Berdasarkan hipotesis 2 yang menyatakan bahwa ada pengaruh positif variabel citra merek terhadap loyalitas pelanggan dapat ditunjukkan dengan melihat Tabel 1 bahwa nilai signifikansi variabel citra merek berada di bawah 0.05, yaitu 0,019 yang berarti bahwa hasil pengujian signifikan pada taraf nyata 5\% sehingga dapat dijelaskan variabel citra merek mempunyai pengaruh yang signifikan terhadap loyalitas pelanggan. Sehingga dapat disimpulkan H2 dapat diterima.

Berdasarkan hipotesis 3 yang menyatakan bahwa ada pengaruh positif variabel harga terhadap loyalitas pelanggan dapat ditunjukkan dengan melihat Tabel 1 bahwa nilai signifikansi variabel harga berada di bawah 0.05 , yaitu 0,001 yang berarti bahwa hasil pengujian signifikan pada taraf nyata 5\% sehingga dapat dijelaskan variabel harga mempunyai pengaruh yang signifikan terhadap loyalitas pelanggan. Sehingga dapat disimpulkan H3 dapat diterima.

Berdasarkan hipotesis 4 yang menyatakan bahwa ada pengaruh positif variabel kualitas produk terhadap loyalitas pelanggan dapat ditunjukkan dengan melihat Tabel 1 bahwa nilai signifikansi variabel kualitas produk berada di bawah 0.05 , yaitu 0,002 yang berarti bahwa hasil pengujian signifikan pada taraf nyata 5\% sehingga dapat dijelaskan variabel kualitas produk 
mempunyai pengaruh yang signifikan terhadap loyalitas pelanggan. Sehingga dapat disimpulkan H4 dapat diterima.

Selanjutnya pada Tabel 1 dapat juga dilihat besarnya koefisien determinasi (Adjusted $\mathrm{R}$ Square) adalah 0,631. Hal ini menunjukkan bahwa sekitar 63,1 \% loyalitas pelanggan pada handphone Xiaomi di Yogyakarta dapat dijelaskan oleh variabel kepuasan pelanggan, citra merek, harga dan kualitas produk, sedangkan sisanya sebesar 36,1\% dipengaruhi oleh variabel-variabel yang lain.

\section{Pembahasan}

Berdasarkan hasil pengujian data serta analisis teori maka dapat disimpulkan terdapat pengaruh yang signifikan dan positif variabel kepuasan pelanggan, citra merek, harga dan kualitas produk terhadap loyalitas pelanggan pada handphone Xiaomi.

Hasil penelitian ini mendukung penelitian yang dilakukan oleh Ranto (2017) yang menjelaskan bahwa kepuasan pelanggan berpengaruh positif terhadap loyalitas pelanggan. Hasil penelitian juga ini mendukung penelitian yang telah dilakukan Tomida dan Satrio (2016) yang menyatakan bahwa harga dan citra merek memiliki dampak yang signifikan terhadap pembentukan loyalitas pelanggan. Selain itu, Suwarni dan Mayasari (2011) menambahkan bahwa melalui kepuasan pelanggan, loyalitas pelanggan dapat dipengaruhi oleh kualitas produk dan harga. Dapat ditambahkan juga bahwa hasil penelitian ini mendukung penelitian yang telah dilakukan Saidani dan Ramadhan (2013) tentang pengaruh iklan dan kualitas atribut produk terhadap loyalitas pelanggan Smartphone Samsung Seri Galaxy.

Berdasarkan Muwarni (2004) yang menyatakan faktor utama yang harus diperhatikan untuk meningkatkan loyalitas pelanggan yaitu kualitas pelayanan, pelanggan akan merasa puas bila mereka mendapatkan pelayanan yang baik atau yang sesuai dengan yang diharapkan; emosional, pelanggan akan merasa bangga dan mendapatkan keyakinan bahwa orang lain akan kagum terhadap dia apabila menggunakan produk dengan merek tertentu yang cenderung mempunyai tingkat kepuasan yang tinggi; dan biaya, pelanggan yang tidak perlu mengeluarkan biaya tambahan atau tidak perlu membuang waktu untuk mendapatkan suatu produk atau jasa cenderung puas terhadap produk atau jasa tersebut.

Selain itu Arianto (2003) menyatakan harga mempunyai peranan penting dalam dalam proses pengambilan keputusan yaitu peranan alokasi dari harga adalah membantu para pembeli untuk memutuskan cara memperoleh manfaat atau utilitas tertinggi yang diharapkan berdasarkan kekuatan daya belinya. Dengan demikian adanya harga dapat membantu para pembeli untuk memutuskan cara pengalokasian kekuatan membelinya pada berbagai jenis barang dan jasa. Pembeli membandingkan harga dari berbagai alternative yang tersedia kemudian memutuskan alokasi dana yang dikehendaki.

Selanjutnya, sebagaimana dijelaskankan oleh Tjiptono (2007) bahwa didalam pembelian, konsumen biasanya memperhatikan bagaimana kualitas produk yang ditawarkan berkenaan dengan manfaat yang akan diperolehnya apakah sesuai dengan yang diharapkan atau tidak. Jika kualitas produk sesuai dengan harapan maka akan dilakukan pembelian dan begitu juga sebaliknya.

\section{KESIMPULAN DAN SARAN}

\section{Kesimpulan}

Berdasarkan hasil analisis yang telah dilakukan maka dapat diambil kesimpulan: Kepuasan Pelanggan (X1), citra merek (X2), harga (X3) dan kualitas produk (X4) berpengaruh positif dan signifikan terhadap loyalitas pelanggan pada Handphone Xiaomi di Yogyakarta. 


\section{Saran}

Berdasarkan hasil penelitian yang telah dilakukan, saran untuk perusahaan perlu terus mempertahankan kepuasan pelanggan, kualitas produknya dan citra merek agar konsumen dapat tetap loyal pada handphone Xiaomi.

\section{DAFTAR PUSTAKA}

Anderssen, T.W., (1994), Satisfaction, Loyalty and Reputation as Indicators of Customer Orientation in the Public Sector. International Journal of Public SectorManagement, Vol. 7, No.2, pp.16-34.

Arianto, A.B., (2003), Pengaruh Atribut Produk, Harga, Kebutuhan Mencari Variasi dan Ketidakpuasan Konsumen Terhadap Keputusan Perpindahan Merek dari Samsung Galaxy Series di Kota Malang, Jurnal Aplikasi Manajemen, Volume 11, Nomor 2, Juni, Hal. 294305.

Arikunto, S., (2003), Prosedur Penelitian, Edisi Revisi Lima, Jakarta, Rineka Cipta.

Cronin, J.J. Jr \& S.A Taylor, (1992), Measuring Service Quality: A Reexamination and Extension, Journal of Marketing, 56: pp.55-68.

Dharmmesta, B.S., dan Irawan, H., (2002), Manajemen Pemasaran Modern: Liberty, Yogyakarta.

Ferrinadewi, E., (2008), Merek dan Psikologi Konsumen, Implikasi pada Strategi Pemasaran. Yogyakarta: Graha Ilmu.

Kandampully, J and D. Suhartanto, (2000), Customer Loyalty in The Hotel Industry: The Role of Customer Satisfaction and Image, Journal of Contemporary Hospitality Management, 12/6, pp. $346-351$.

Kotler, P., (2002), Manajemen Pemasaran, Edisi Milenium, Salemba Empat, Jakarta.

Kotler, P., dan Amstrong, G., (2012), Prinsip - Prinsip Pemasaran, Edisi 12 Jilid 1, Erlangga, Jakarta.

Kotler, Philip dan Keller, Kevin Lane, (2012), Manajemen Pemasaran, Edisi Ke 13 Jilid 2, Erlangga, Jakarta.

Muwarni, F.D., (2004), Kualitas Layanan dan Kepuasan Pelanggan sebagai Penentu Loyalitas Pelanggan: Kajian Teoritis dan Metodologis untuk Penelitian. Ekonomi Bisnis Thn. 9 No. II. Malang: Universitas Negeri Malang.

Prawirosentono, S., (2004), Filosofi Baru Tentang Manajemen Mutu Terpadu Abad 21, Penerbit Binarupa Aksara: Jakarta.

Ranto, D.W.P., (2014), Dampak Ketidakpuasan Konsumen Pada Terbentuknya Perilaku Berpindah Merek (Brand Switching), Jurnal Bisnis, Manajemen, Dan Akuntansi, Vol. 2, No. 2, Sep. Hal. $83-90$.

Ranto, D.W.P., (2017), Pengaruh Citra Toko terhadap Kepuasan Pelanggan \& Loyalitas Pelanggan di Yogyakarta", Jurnal Bisnis, Manajemen, Dan Akuntansi, Vol. IV, No 2, September, hal. 1 -11 .

Saidani, B. dan Ramadhan, D.R., (2013), Pengaruh Iklan dan Atribut Produk Terhadap Kepuasan pelanggan Smartphone Samsung Seri Galaxy (Survei Pada Pelanggan ITC Roxy Mas), Jurnal Riset Manajemen Sains Indonesia (JRMSI) ,Vol. 4, No. 1, Hal. 53-73. 
Sekaran, U., (2000), Research Methods for Business; A skill Building Approach. (3rd ed.). New York: Jhon Wiley \& Sons, Inc.

Selnes, F., (1993), An Examination of the Effect of Product Performance on Brand Reputation, Satisfaction and Loyalty," European Journal of Marketing, Vol. 27, No. 9, pp. 19-35.

Sugandini, D., (2003), Anteseden Loyalitas Konsumen pada Industri Perhotelan (Studi pada Hotel berbintang di Daerah Istimewa Yogyakarta) : Wahana, Vol. 6, no.2, p. 181-200.

Suwarni dan Mayasari, S.D., (2011), Pengaruh Kualitas Produk Dan Harga Terhadap Loyalitas Melalui Kepuasan Konsumen, Jurnal Ekonomi Bisnis, Vol. 16, No. 1, Maret, hal. 76 - 84.

Tjahjono, H.K., (2015). Metode Penelitian Bisnis. Visi Solusi Madani

Tjiptono, F., (1997), Strategi Pemasaran, Edisi Ketiga. Andi, Yogyakarta.

Tjiptono, F., (2002), Total Quality Manajemen Edisi Revisi. Andi, Yogyakarta.

Tomida, M., dan Satrio, B., (2016), Pengaruh Harga Dan Citra Merek Terhadap Loyalitas Pelanggan Produk Footwear Yongki Komaladi, Jurnal Ilmu dan Riset Manajemen : Volume 5, Nomor 7, Juli, hal. 1 - 15.

Xian, Gou Li, dkk., (2011), Corporate-, Product-, and User-Image Dimensions and Purchase Intentions. Journal of Computers, (6) 9: 1875-1879. 